\title{
The Religious Concept of the Dual Character of the Turtle in Graeco-roman Egypt
}

\author{
Marwa Abd el-Maguid el-Kady \\ Lecturer in Tourist Guiding Department, \\ Faculty of Tourism and Hotels, \\ Alexandria University
}

The ancient Egyptian mythology is full of contradictories concerning the Malevolent and benevolent natures of certain Egyptian deities. In early Egyptian times, the turtle, especially that Nile turtle of Trionyx triunguis was regarded as useful animal of which meat was eaten from pre-dunastic period till the Old Kingdom. However, this concept did not remain the same in later periods. From at least the Middle Kingdom, the Nile turtle for some reason was considered a symbol of evil and was rendered an enemy of $\mathrm{Re}$, and hence has to be destroyed in certain rituals. It was during the Graeco-roman period, that the turtle's nature according to religious beliefs held the two contradicted tokens; the malevolent and benevolent. Most researches focused on the malevolent nature of the turtles in the concern of being an enemy of Re that played a role in magical and medical practices ignoring the benevolent role which the Nile turtle played in the Egyptian religious conception during the Graecoroman period. Therefore, the research aims at reflecting the double nature of the Nile turtle during the Graeco-roman period and analyzing the reasons and significances beyond this duality.

Generally, the turtle was known in ancient Egyptian as

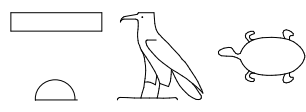
$\check{s}^{\prime} t y w^{l}$. The name Sheteu designates specifically the Nile soft-shell turtle, or the Trionyx triunguis ${ }^{2}$, which is characterized by its ability to endure long

${ }^{1}$ Erman, Adolf and Grapow, Herman, Wörterbuch der Aegyptischen Sprache, vol.IV, Berlin, 1971, 556, no.7; Gardiner, Alan Henderson, Egyptian Grammer: Being an Introduction to the Study of Hieroglyphs, $3^{\text {rd }}$ ed., Griffith Institute, Ashmolean Museum, Oxford, 1957, 595 (I 2); Faulkner, R.O., A Concise Dictionary of Middle Egyptian,

Oxford, 1964, 273. At the same time, $\rightleftharpoons$ or the turtle-constellation, Erman, Adolf and Grapow, Herman, Wörterbuch der Aegyptischen Sprache, vol.IV, 557, no.5; Faulkner, R.O., A Concise Dictionary of Middle Egyptian, 273; Budge, E.A. Wallis, From Fetish to God in Ancient Egypt, New York, 1988, 92. It was represented as one of the 36 decans depicted on the underside of the Middle Kingdom coffin lids down to the Ptolemaic period. It is figured as a pair of turtles, sometimes viewed from beneath, Fischer, Henry G., 'Schildkröte', in Lexikon der Ägyptologie, vol. V, Wiesbaden, 1982, 628.

${ }^{2}$ Hoath, Richard, A Field Guide to the Mammals of Egypt, $2^{\text {nd }}$ ed, The American University in Cairo Press, Cairo, 2009, 10; Franklin, Carl J., Turtles: An Extraordinary Natural History 245 Million Years in Making, Minnesota, 2007, 136. It is also known as Trionyx egyptiacus, as it inhabits the Nile and devours the little crocodiles when they proceed from eggs, Cuvier, George, Griffith, Edward and Pidgeon, Edward, The Class Reptilia, London, 1831, 96. Other species of turtle and tortoise were also known in 
periods without breathing (one-two hours) underwater ${ }^{3}$, and its length can reach one meter. Its colour varies between dark brown to olive ${ }^{4}$. In late period, its name was modified into $s t$, thus "the mysterious one" 5 that can be interpreted as "the one who is hidden" derived from $\subset \square$ $s t 3$ meaning "be a secret" or "being hidden" ${ }^{6}$. Thus its name means "the one who is hidden" the bottom of watery pools. Moreover, the inscriptions from the Graecoroman period identifies the turtle also as $\Longleftarrow$ or $\rightleftharpoons$ t3-hnKt (bread-bier) $^{8}$ with a determinative of a turtle as $\varlimsup_{0}$.

The turtles were first attested in pre-dynastic period as stone and terracotta figurines, and vessels ${ }^{10}$, in addition to dark schist palettes that took the form of a turtle from the Gerzean period (Naqada II) that were used to grind malachite and galena eyeliner ${ }^{11}$. Turtles' carapaces were used throughout the ancient Egyptian history in different ornamental purposes; including knife handles, braceltes, toilet articles, and bowls. Zooarchaeological evidences prove that turtle's meat was one of the nutrient elements of the Egyptian diet from the pre-dynastic period up till

ancient Egypt; like Tesudo kleinmanni which ia a tortoise that lives on land, characterized by a high domed carapace that was used in the New Kingdom as sound-box for lotus and bowls, Fischer, Henry G., 'Schildkröte', 627. There is also Chelonian mydas, which is the salt-water Green turtle that was utilized in manufacturing implements and ornaments like combs, bracelets from pre-dynastic to the New Kingdom and knife hilts from the end of the Middle Kingdom, Fischer, Henry G., "Schildkröte', 627 and Eretmochelys imbricate or the Red Sea turtle, Houlihan, Patrick F., The Animal World of the Pharaohs, American University in Cairo Press, Cairo, 1996, 125.

${ }^{3}$ Mackal, Roy P., Living Dinosaurs?: In Search of Mokele-Mbembe, Leiden, 1987, 270.

${ }^{4}$ Barbour, Roger W. and Enst, Carl H., Turtles of the World, Smithsonian Institution

Press, Washington, 1989, 100.

${ }^{5}$ Fischer, Henry G., 'Egyptian Turtles”, in Bulletin of the Metropolitan Museum of Art24

No.6, 1966, 195.

${ }^{6}$ Erman, Adolf and Grapow, Herman, Wörterbuch der Aegyptischen Sprache, vol.IV, 551, Gardiner, Alan Henderson, Egyptian Grammar, 595; Faulkner, R. O., A Concise Dictionary of Middle Egyptian, 273.

${ }^{7}$ Wilson, Penelope, Sacred Signs: Hieroglyphs in Ancient Egypt, Oxford University Press, Oxford and New York, 2003, 116.

${ }^{8}$ Erman, Adolf and Grapow, Herman, Wörterbuch der Aegyptischen Sprache, vol.V, 221, nos.3,4.

9 Gutbub, Adolphe, ,'La tortue animal cosmique bénéfique', Hommages à Serge Sauneron I, Égypte pharaonique, Cairo, 1979, 392, 427.

${ }^{10}$ Houlihan, Patrick F., The Animal World of the Pharaohs, 122; Fischer, Henry G., 'Schildkröte', 627.

${ }^{11}$ For pre-dynastic period palettes and vessels figured as turtles, see Vandier, Jacques, Manuel d'archéologie égyptienne, volI, Paris, 1988, 381-82 (4º), fig.258; Cialwicz, L. M., Les palettes égyptiennes aux motifs zoomorphes et sans decorations, Studies in Ancient Art and Civilization 3, Kraków, 1991, 35-7; Petrie, W. M. Flinders, Prehistoric Egypt, British School of Archaeology in Egypt and Egyptian Research Account Twentythird Year 1917, London, 1920, 37. 
the Old Kingdom ${ }^{12}$. However, turtles are completely absent from the offering lists, offering tables and slaughtering scenes of the Old Kingdom tombs ${ }^{13}$. Later, in Middle Kingdom, certain parts were used as remedies for certain diseases as well ${ }^{14}$.

This animal that lived in the deep and dark waters of the Nile, the turtle was regarded as symbol of evil since late Old Kingdom. It became associated with the solar cult, as it was regarded as the enemy of Re, due to its dark nature living underwater ${ }^{15}$. Therefore, in coffin texts, the turtle's meat is considered an abomination to $\mathrm{Re}^{16}$, and thus $\mathrm{Re}$ could not eat the meat of his worst enemy ${ }^{17}$. The New Kingdom coffin texts state phrases that confirm this fact, that the turtle was an enemy of Re; like $f \circ$. According to this myth, the turtle could hinder the way of Re's bark in the underworld. Therefore, this spell was made for warding off the evil of the

\footnotetext{
${ }^{12}$ Houlihan, Patrick F., The Animal World of the Pharaohs, 122; Fischer, Henry G., 'Egyptian Turtles', 194.

${ }^{13}$ De Meyer, Marleen; Van Neer, Wim; Peeters Christoph and Willems, Harco, 'The Role of Animals in the Funerary rites at Dayr a-Barshā', in Journal of the American Research Center in Egypt 42, 2005/2006, 69.

${ }^{14}$ Fischer, Henry G., 'Egyptian Turtles', 194. Ebers Medical Papyrus mentions employment of turtle's organs and carapace in certain formulae. The papyrus was found in Theban necropolis at Assassif, and now in the University Library of Leipzig. It is one of the longest Egyptian medical papyrus It comprises 110 pages of remedies of certain diseases, dated from the time of the New Kingdom (under Amenhotep I), Nunn, John F., Ancient Egyptian Medicine, London, 1996, 30-2. For instance, the turtle's organs were mentioned to cure eye's illnesses, Nunn, John F., Ancient Egyptian Medicine, 202.

${ }^{15}$ Houlihan, Patrick F., the Animal World of the Pharaohs, 122. However, Loret thinks the turtle is identified with the Abdw fish which was a friendly helper of the sun god, Bonnet, Hans, Reallexikon der ägyptischen Religionsgeschichte, Berlin, 1952, 681. The fish of 2 S believes that it is not a fish at all, but a species of piloting the boat of the sun god. Loret ber that it is not a fish at all, but a species of tortoise, specially Trionyx aegyptiacus, Loret, Victor, 'Notes sur la faune pharaonique', in Zeitschrift fur Ägyptische Sprache und Altertumskunde 30, 1892, 29. This is not convincing as the word always has the fish determinative and never the $20-5$ or the He also ignores the mythological association of the fish with the sun god. Whereas the turtle was the enemy of Re, the $3 b \underline{d} w$ fish swimming in front of the sun god's boat on coffins. It can be said with certainity that $3 b \underline{d} w$ is a fish and not a reptile, Dawson, Waren R., 'Studies in the Egyptian Medical Texts-II', in Journal of Egyptian Archaeology 19, 1933, 137.

${ }^{16}$ Fischer, Henry G., 'Schildkröte', 627.

${ }^{17}$ Meeks, Dimitri andFavard-Meeks, Christine, Daily Life of the Egyptian Gods, translated from French by Goshgarian, G. M., Cornell University Press, New york, 1996, 65. See CT $\mathrm{V}, 30$ (spell 368), the deceased is prohibited to eat excrement "if you make me eat this (excrement), then Re will eat turtles", Gutbub, Adolphe, 'La tortoue animal cosmique bénéfique', 405.

${ }^{18}$ Erman, Adolf and Grapow, Herman, Wörterbuch der Aegyptischen Sprache, vol.IV, 557, no.4.

${ }^{19}$ Andrews, Carol, Amulets of Ancient Egypt, British Museum Press, London, 1994, 36; Manfred, Lurker, Götter und Symbole der Alten Ägypten, $2^{\text {nd }}$ ed., Munich, 1981, 163; Gutbub, Adolphe, 'La tortue animal cosmique bénéfique', 408.
} 
underwater turtle ${ }^{20}$. Occasionally, at least from the nineteenth dynasty on, the turtle was identified with the serpent Apophis ${ }^{21}$. In Papyrus BremnerRhind $^{22}$, the turtle is mentioned among the dangerous creatures which bore the name of Apophis "Apopi the enemy, the turtle" ${ }^{23}$ living in the dark water of the Nile waiting to impede the night bark of $\mathrm{Re}^{24}$. In addition, in the Book of the Dead, the turtle is also known as an enemy of Re. In chapter 161, Thoth repeats the phrase: "May Re live and turtle die"25.

Being an embodiment of danger symbolizing darkness and death, the turtle-amulets were used for protection from evil, and its wearer wished to avoid death and danger ${ }^{26}$. The oldest of these date from the Neolithic Period up to the late and Greco-roman times. Turtle-amulets were made of various materials including green or blue glazed composition, amethyst, ivory, serpentine, molded hollow sheet-gold and in particular cornelian, olivine and green jasper. There are two distinct forms of these amulets: one naturalistically represents the head, legs and tail emerging from the shell; the other is shaped as a convex disc with a protruding head ${ }^{27}$. Moreover, turtles are also represented on magical knives and rods (fig.1) from the Middle Kingdom ${ }^{28}$, as it was considered a vicious biter that could grape its victims suddenly when it was in reach to keep evil and harm forces at a distance ${ }^{29}$. It is invoked as a helper against dangers and evil spirits $^{30}$.

\footnotetext{
${ }^{20}$ Bonnet,Hans, Reallexikon der ägyptischen Religionsgeschichte, 681.

${ }^{21}$ Fischer, Henry G., 'Schildkröte', 627; Gutbub, Adolphe, 'La tortue animal cosmique bénéfique', 398 .

${ }^{22}$ It is dated from the fourth century B.C. (312-311 B.C.), now in the British Museum in London (P. BM 10188). The papyrus bear four works: Songs of Isis and Nephthys, The ritual of Bringing in Sokar, the Book of Overthrowing Apep, and the Names of Apep, that shall not be, Faulkner, R. O., 'The Bremner-Rhind Papyrus I: The Songs of Isis and Nephthys', in Journal of Egyptian Archaeology 22, 1936, 121.

${ }^{23}$ Gutbub, Adolphe, 'Latortue animal cosmique bénéfique', 396; Faulkner, R. O., The

Papyrus Bremner-Rhind (British Museum $n^{\circ}$ 10188), Bibliotheca Aegyptiaca 3, Brussels, 1933, 54, 14.

${ }^{24}$ Andrews, Carol, Amulets of Ancient Egypt, 36. For enmity of Apophis against Re, see Borghouts, J. F., 'The Evil Eye of Apohis', in Journal of Egyptian Archaeology 59, 1973, 114-50.

${ }^{25}$ (Papyrus of Ani), Faulkner, Raymond, The Egyptian Book of the Dead: The Book of Going Forth by Day, San Francisco, 1994, 125; Manfred, Lurker, Götter und Symbole der Alten Ägypten, 163; Gutbub, Adolphe, 'La tortue animal cosmique bénéfique', 397.

${ }^{26}$ Arnold, Dorthea, 'An Egyptian Bestiary', in Bulletin of the Metropolitan Museum of Art 52, No. 4, 1995, 34.

${ }^{27}$ Andrews, Carol, 'Amulets of Ancient Egypt, 10, 36. For examples of turtle amulets, see Fischer, Henry G., 'Egyptian Turtles', 197.

${ }^{28}$ The magic rods were symbols of authority, held by kings and priests and magicians in order to establish power foor these personalities over the creatures figured on the rods, Pinch, Geraldine, Magic in Ancient Egypt, British Museum Press, London, 199, 42.

${ }^{29}$ Houlihan, Patrick F., The Animal World of the Pharaohs, 125; Harris, Eleanor L., Ancient Egyptian Devination and Magic, Massachusetts, $2^{\text {nd }}$ ed., 1998, 49; Gutbub, Adolphe, 'La tortue animal cosmique bénéfique', 399.

${ }^{30}$ Steindorff, George, 'The Magical Knives of Ancient Egypt', in The Journal Of Walters Art Gallery 9, 1946, 49.
} 
Moreover, Budge suggests the existence of a turtle god in funeral texts

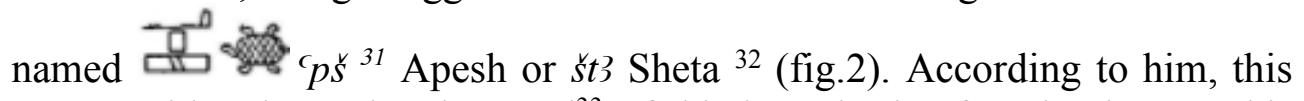
was considered a malevolent god ${ }^{33}$. If this hypothesis of Budge is true, this god must have been the demon that is described in the Middle Kingdom coffin texts as "turtle-faced" and in the New Kingdom (starting from the ninteenth dynasty) coffin texts as "eater of filth", and may have been originated from the turtle-headed man ${ }^{34}$. This opinion is strongly supported by the discovery of wooden statuettes representing a turtle- headed man from the New Kingdom. A good example of these wooden turtle-headed statuettes is the one found in the Valley of the Kings, in tomb KV 57 of Horemheb and now in the British Museum (EA 5704) (fig.3). The question is what was the function of such demon? Most probably it was used as a guardian to protect the king in his journey in the other world ${ }^{35}$. The fact that the turtle was used as a demon rather than a god is reflected on a New Kingdom sarcophagus that bears the same spell "may Re live and may the turtle die". Interestingly, the determinative of the turtle in this text is represented in profile not from the top or bottom as usual. Moreover, it is to be noticed that the artist replaced the turtle's paws in this case with two pairs of human legs ${ }^{36}$. (fig.4).

In the New Kingdom as well, the turtle along with the hippopotamus were considered symbols of evil that had to be destroyed with harpoons ${ }^{37}$. An important proof of this fact can be concluded from a Nile-turtle spearing-scene found in a nineteenth dynasty tomb of Nebwenenef (no.157, Thebes) at Dra Abu el-naga ${ }^{38}$. The tomb's owner is shown spearing a tiny Nile-turtle from a raft in a papyrus swamps to symbolize victory over evil power accompanied by the traditional spell "Mar Re live and the turtle die" ${ }^{39}$ (fig.5).

\footnotetext{
${ }^{31}$ Budge, E. A. Wallis, Egyptian Hieroglyphic Dictionary, Part I, Montana, 2003, 119.

${ }^{32}$ Budge, E. A. Wallis, From Fetish to God in Ancient Egypt, New York, 1988, 92; Johnson, Charles Williams, The Sound of Meaning, Kansas, 2004, 83.

${ }^{33}$ Budge, E. A. Wallis, The Gods of the Egyptians or Studies in Egyptian Mythology, vol.II, Chicaago, 1904, 376.

${ }^{34}$ Fischer, Henry G., "Schildkröte”, 628; Gutbub, Adolphe, 'La tortue animal cosmique bénéfique', 408.

${ }^{35}$ Russmann, Edna R. and James, Thomas G., Eternal Egypt: Masterwrks of the Ancient Art from the British Museum, British Museum Press, 2001, London, 160.

${ }^{36}$ Fischer, Henry G., 'Egyptian Turtles', 195.

${ }^{37}$ Fischer, Henry G., "Schildkröte", col627.

${ }^{38} \mathrm{He}$ was the high priest of Amun under Ramsses II, Arnold, Dieter, The Encyclopedia of Ancient Egyptian Architecture, London and New York, 2003, 159. For the scene, see SäveSöderbergh, T., 'Eine ramessidische Darstellung von Töten der Schildkröte', in Mitteilungen des Deutschen Archäologischen Instituts 14, 1956, 175-80; Säve-Söderbergh, T., 'On Egyptian Representations of Hippopotamus Hunting as A Religious Motive”, Horae Soederblomainae 3, 1953, 39-40.

${ }^{39}$ Fischer, Henry G., 'Egyptian Turtles', 200.
} 
Later, the turtle was represented in scenes being spread and destroyed on the walls of the temples from the Graeco-roman period. The turtle in these scenes are shown being harpooned by the king as a religious ritual ${ }^{40}$ along with the other malevolent creatures ${ }^{41}$. The massacre of turtle was thus a religious ritual assimilated with the rites of the massacre of the hippopotamus as enemy of $\mathrm{Re}^{42}$. This ritual was known as "slaughtering the turtle" in which the king is represented in the form of the god Onuris spearing the turtle in front of $\mathrm{Re}^{43}$. The best example of the massacre of turtle is figured on the walls of Edfu temple as an episode of the series of Horus defeating the dangerous creatures symbolizing the myth of Horus defeating Seth ${ }^{44}$ (fig.6).

Moreover, the theme of the massacre of the turtle is also associated with solar believes. This ritual is figured among the rituals that aimed at destroying the enemies of $\mathrm{Re}$ in the second and third hours of the Ptolemaic version of the Book of the Day ${ }^{45}$. Being an enemy of Re is also emphasized by another important fact, which is the name of the turtle itself that was modified in late period into $-5 t$ ) or "the one who is hidden". This was also a name given to Seth in the texts inscribed on the walls of Ptolemaic temples. Hence, the turtle was considered as a substitute for Seth ${ }^{46}$.

Concerning the benevolent nature of the turtle that is boldly noted in the Graeco-roman period, it is clear that the turtle was closely connected then with the Nile inundation. It was thought that the turtle commanded the arrival or non-arrival of the flood. In papyrus Jumilhac ${ }^{47}$ (XVII, 26-XVIII, 1 ), it is mentioned that: "the mouth of the turtle is closed" as a metaphor of the shortage of the flood ${ }^{48}$. Thus, the turtle played a cosmic function being in religious conception responsible for supplying the Nile with water. This means that the turtle is also responsible for the non-flooding. In this

\footnotetext{
${ }^{40}$ Fischer, Henry G., 'Egyptian Turtles', 200; Vassilika, E., Ptolemaic Philae, Orientalia Lovaniensia Analecta, Leuven, 1989, 104.

${ }^{41}$ Houlihan, Patrick, The Animal World of the Pharaohs, 122-4; Fischer, Henry G., 'Schildkröte', 627; Andrews, Carol, Amulets of Ancient Egypt, 36.

${ }^{42}$ Gutbub, Adolphe, 'La tortue animal cosmique bénéfique', 397.

${ }^{43}$ Manfred, Lurker, Götter und Symbole der Alten Ägypten, 162. Slaughtering the turtle that attacks the bark of Re does not result from a true myth, but simply the turtle replaces Apophis. This is well represented by the formula of ' $n h R^{c}, m t s t w$ (may Re live, and may the turtle die), being replaced in some legends with ' $n h$, $m t$ nik (may Re live and may enemy die) as enemy refers to Apophus, Gutbub, Adolphe, 'La tortue animal cosmique bénéfique', 411-12.

${ }^{44}$ Fairman, H.W., 'The Myth of Horus at Edfu-I', in Journal of Egyptian Archeology 21, 1935, 26-36.

${ }^{45}$ Gutbub, Adolphe, 'La tortue animal cosmique bénéfique', 419.

${ }^{46}$ Wilson, Penelope, Sacred Signs, 116.

${ }^{47}$ It dates from the Ptolemaic period that describes the myth of Osiris and Seth, Frankfurter, David, 'Approaches to Coptic Pilgrimage', in Ed. Frankfurter, David, Pilgrimage and Holy Space in Late Antique, Leiden, 1998, 16.

${ }^{48}$ Gutbub, Adolphe, 'La tortue animal cosmique bénéfique', 423-4.
} 
aspect, it is connected with Apophis, the evil that caused harm to the journey of the sacred bark of $\mathrm{Re}$ by swallowing the water of the underworld river $^{49}$.

In addition, the connection with the Nile is firmly proved by the designation of the turtle on the walls of the Graeco-roman temple as $t 3$ -

hnkt $\rightleftharpoons$ (bread-bier). The geographical procession of the offering room in the temple of Kom Ombo is accompanied by a text addressed to Sobek assimilating him with the turtle as: "you are the turtle ( $t 3-h n k t$ "bread-bier"), which pours the Nile in its branches, to feed created beings, to give subsistence to every mouth which eats, to all the creatures on earth". Being identified with Sobek is understood. Both are aquatic divinities and both in certain cases are assimilated with Apophis. In addition, in a text in Kom Ombo, Sobek is identified as a turtle as follows: "the turtle (bread-bier) that flows like Noun that determined the four regions of the earth as the work of its arms and which greens the arable land with plants, the tree of life emanates from it". Moreover, Sobek is also identified with the turtle being he "who supplies the altar of the gods and goddesses, master of food, which augments the offerings". The text thus emphasizes and focuses on the role of the turtle as a universal creator god identified with Noun ${ }^{50}$.

More interesting is a representation of the turtle surrounded with four red crowns facing the four cardinal points. This depiction can be seen among the mythical celestial motives on the southernmost register on the ceiling of the pronaos of Esna temple ${ }^{51}$ (fig.7). A quite similar representation can be found among hieroglyphic text in the thirteenth column of the great hymn dedicated to Sobek engraved on the exterior face of the south aisle of the pylon of Kom Ombo temple. It is depicted here as a determinative of the word $t 3$ - hnkt "bread-bier" -a designation of the turtle in the Graeco-roman period- shown as a turtle whose frontal and rear paws bear each a red crown ${ }^{52}$ (fig.8). According to Gutbub, this theme represents the fertile land of Egypt fertilized by the Nile figured as the turtle as being bordered by the red crowns symbolizing the red lands or the deserts which bordered Egypt from the two sides east and west. Moreover, he interprets the former depiction on the ceiling of Esna as a reflection to this hypothesis representing Egypt bordered by deserts on the two sides and traversed by the Nile represented by the turtle itself ${ }^{53}$.

\footnotetext{
${ }^{49}$ Gutbub, Adolphe,'La tortue animal cosmique bénéfique', 425.

${ }^{50}$ Gutbub, Adolphe,'La tortue animal cosmique bénéfique', 427-9.

${ }^{51}$ Gutbub, Adolphe,'La tortue animal cosmique bénéfique', 391; Sauneron, Serge, le temple d'Esna, vol.4, Institute Français d'Archéologie Orientale, Cairo, 1969, XVII.

${ }^{52}$ Gutbub, Adolphe,'La tortue animal cosmique bénéfique', 392.

${ }^{53}$ Gutbub, Adolphe,'La tortue animal cosmique bénéfique', 433-4.
} 
This is a good indication that turtle has a double character, malevolent and more interesting a benevolent. A good proof of not being malevolent in late period is figured on the cippi of Horus, in which Horus the Child appears eliminating a number of malevolent animals and creatures. A good example is attested by the well-known Metternich Stela ${ }^{54}$ on which Horus the child appears grasping the evil creatures including serpents, scorpions, lions, the animal of Seth, while trampling on a crocodile ${ }^{55}$ (fig.9). It is notable that the turtle is not depicted among those malevolent creatures. Another depiction of the same type can be found on another cippius of Horus ${ }^{56}$, which shows Horus grasping the same animals again excluding the turtle from the dangerous animals that are destroyed by Horus $^{57}$. However, on the reverse at the top of the Metternich stele, the turtle as a malevolent is shown among evils figured in a representation of a mythical god ${ }^{58}$ standing on an oval ring that encloses a depiction of dangerous creatures from right to left: panther, two serpents, animal of Seth, crocodile, scorpion, hippopotamus, and turtle at the center ${ }^{59}$ (fig.10).

It is understood thus that the physical nature of the turtle, specifically Trionyx triunguis, or in other words the Nile turtle, affected the Egyptian religious conception in many aspects. First, its habit to remain for hours underwater without breathing and its ability to hide in the mud caused it to be a symbol of mystery to the ancient Egyptians that led the Egyptians to name it styw or "the mysterious one" $"$. Second, being a creature that can live in the darkness of the underwater caused it to be an enemy of Re that may attack the sun's boat during its journey in the darkness of the underworld. In this case, the turtle was identified with the serpent Apophis, the great enemy of Re. This concept was the reason beyond the usage of traditional formula "May Re live and turtle die" to protect the sun god from his enemy the turtle. On the other hand, being a common creature of the Nile, the ancient Egyptians specifically in the Graeco-roman period connected it with the flooding of the river and made it responsible for the arrival of the inundation. This means that by the Graeco-roman period, the turtle as a

\footnotetext{
${ }^{54}$ The most famous "cippus of Horus", made of dark grey-green greywacke, in Metropolitan Museum of Art in New York (Accession No.50.85), from the time of Nectanebo II of the thirtieth dynasty, presented by Mohammed Ali Pasha in 1828 to the Austerian statesman, Scott, Nora E., 'The Metternich Stela', in Bulletin of Metropolitan Museum of Art 9, No.8, 1851, 201.

${ }^{55}$ Scott, Nora E., 'The Metternich Stela', 206.

${ }^{56}$ Made of limestone, in the Museum of Seized Antiquities at the Citadel in Cairo, (inventory no.379), dated to the first half of the first millennium B.C., Kákosy, László and Moussa, Ahmed, 'A Horus Stela with Meret Goddess”, in Studien zur Altägyptischen Kultur 25, 1998, 143.

${ }^{57}$ See Kákosy, László and Moussa, Ahmed, 'A Horus Stela with Meret Goddess”,145, fig. 1 .

${ }^{58}$ Scott, Nora E., 'The Metternich Stela', 208.

${ }^{59}$ Budge, E. A. Wallis, The Gods of the Egyptians, 273.

${ }^{60}$ Fischer, Henry G., 'Egyptian Turtles', 195.
} 
religious significance bore in its core not only the malevolent nature, but the benevolent as well.

It is also comprehended that being an animal of the shadowy deep water, the turtle possessed a dual character for the ancient Egyptians: a cosmic danger and thus ritually annihilated, and at the same time it possessed power that can ward off evil ${ }^{61}$. In fact, the benevolent nature of the turtle although being strongly emphasized during the Graeco-roman period, apparently on the walls of the Graeco-roman temples, can also be traced back as early as pre-dynastic till the Old Kingdom period, when its meat was part of the Egyptian diet and when it was regarded as a protective symbol against evil. The latter concept remained in use in medical and magical practices as turtles were figured as amulets and represented on magical rods (fig.1). However, it was not an innovation for a dangerous creature like the turtle to bear a benevolent nature that would allow it to be used as amulets and magical practices. In fact, it was an Egyptian tradition to use such creatures as symbols for protection. This can be applied for example on crocodiles, serpents, scorpions and hippopotami. The ancient Egyptians believed in the two natures of these creatures, although being dangerous, they can be protectors of dangers. The two qualities of the turtle can also be reflected in the so-called cippi of Horus. For instance on the obverse of the Metternich stele, Horus is eliminating the dangerous animals and creatures excluding the turtle (fig.9), as to emphasize the non-malevolent feature of the turtle. Ironically, on the reverse of the same stele, the turtle is figured among the evil creatures that are enclosed in a circle (fig.10). Thus, the two characters of the turtle can be indicated in one object.

Despite the role which the turtle obviously played in the Egyptian mythology throughout the ancient history, it was not worshipped as a member of the Egyptian pantheon, nor had a sanctuary of its own ${ }^{62}$. Unlike the other dangerous creatures, the turtle for unknown reason was not deified. The hippopotamus for instance was venerated in the form of the goddess Taweret, the scorpion in the form of of the goddess Serqet and the crocodile in the form of the god Sobek. As for the turtle, it was represented as a demon that held a funeral function and appears in funeral texts of the New Kingdom as a turtle-headed man (fig.2), or figured in the same shape as a wooden statuette (fig.3). But, again here, the turtle played a role of protection considering that this demon was used to guard the deceased in the underworld.

The most common theme of 'slaughtering the turtle' is again an aspect of the malevolent nature of the turtle. Although it is a common scene on the walls of the temples from the Graeco-roman period, its root goes back as early as New Kingdom. However, it was connected then with funeral

\footnotetext{
${ }^{61}$ Arnold, Dorothea, 'An Egyptian Bestiary’, 34.

${ }^{62}$ Gutbub, Adolphe, 'La tortue animal cosmique béméfique', 398.
} 
traditions being figured in tombs (fig.5) rather than representation on walls of the temples like Graeco-roman period (fig.6).

It was only during the Graeco-roman period did the benevolent feature of the turtle gain much attention, as being related to the Nile and its inundation. In Kom Ombo, it is described as being responsible for pouring the water into the branches of the Nile and being responsible for the flowing of the flood. In this aspect, it is identified with Noun who was responsible for the feeding and watering all the beings and thus may reach the level of being a creator god. Thus, being connected with the flooding makes the turtle in the position of having a nature of two contradicted characteristics; the benevolent, reflected in its responsibility of causing the flood, and the malevolent represented in the act of being an aspect of Apophis and could swallow the water to cause harm to the sun's bark during its night journey. In addition, the turtle according to the analyzing of Gutbub to the scene of the turtle surrounded with four red crowns in Esna and Kom Ombo temples (fig.7, 8), represents Egypt with its two contradicted qualities the benevolent formed in the Nile that is represented by the turtle and the two flanking deserts east and west represented by the two red crowns on each side of the turtle. 


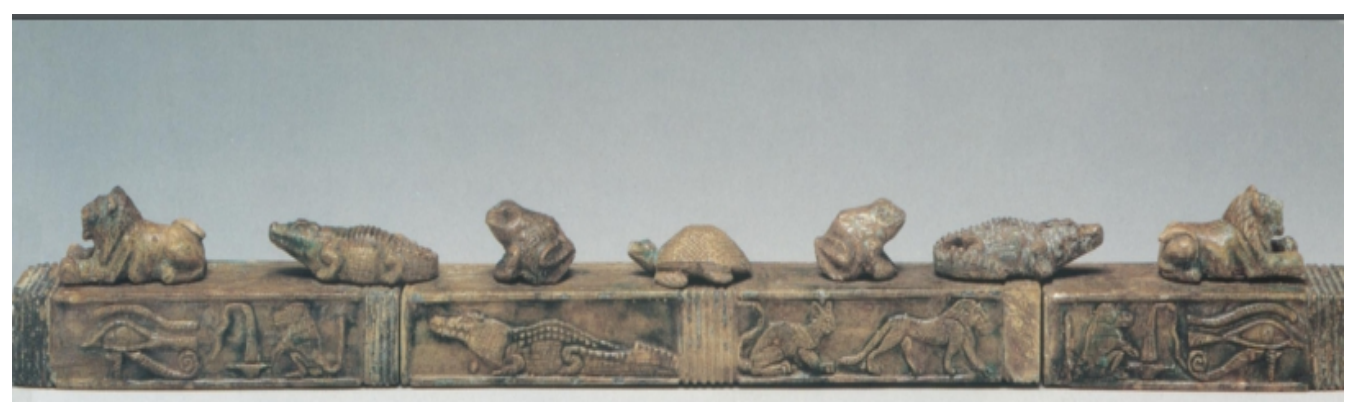

Fig.1 A magic rod from late twelfth dynasty represented with evil creatures centered by a turtle, Metropolitan Museum of Art in New York (Accession no.22. 1. 565)

Arnold, Dorothea, 'An Egyptian Bestiary', the Metropolitan Museum of Art Bulletin 52, No.4, 1995, 35.

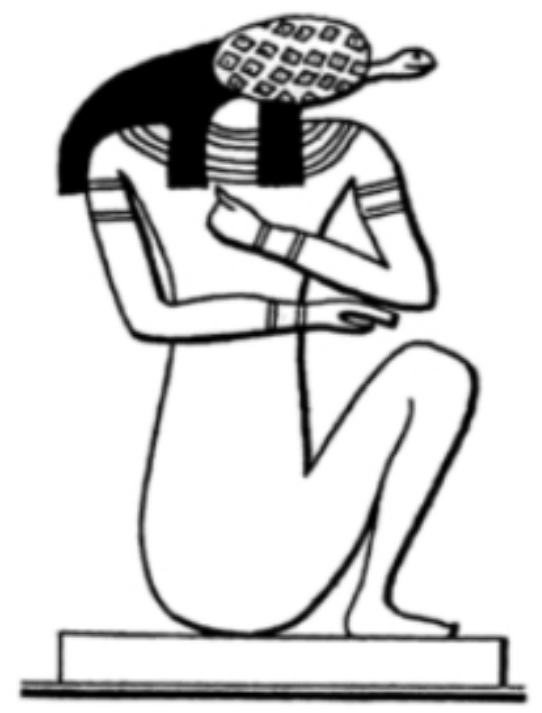

Fig.2 The turtle god

Budge, E. A. Wallis, From Fetish to God in Ancient Egypt, New York, 1988, 93. 


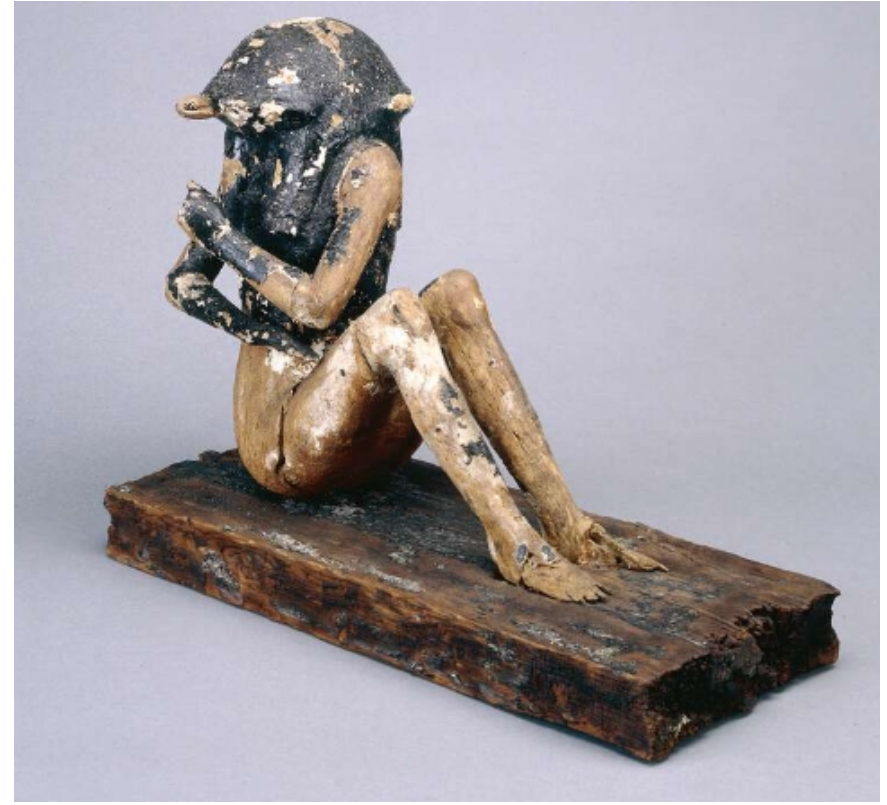

Fig.3 A wooden statuette representing the turtle-headed demon

Russmann, Edna R. and James, Thomas G., Eternal Egypt: Masterworks of the Ancient Art from the British Museum, British Museum Press, London, 2001, 160.



Fig.4 The turtle is represented in profile with human legs Fischer, Henry G., 'Egyptian Turtles', 195, fig.3. 




Fig.5 Scene from the tomb of Nebwenenef (no.157, Thebes) showing the spearing of the turtle in Nile swamps

Fischer, Henry G., 'Egyptian Turtles', in Bulletin of the Metropolitan Museum of Art 24 No.6, 1966, 199, fig. 12.

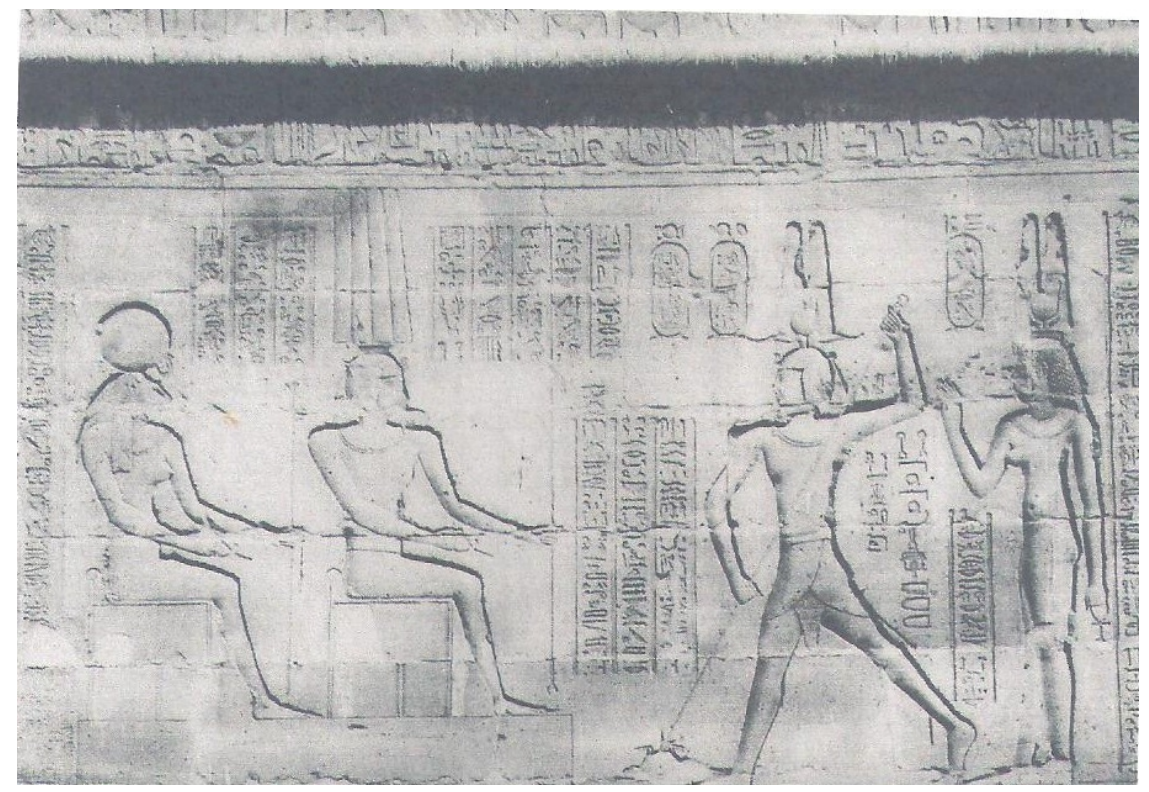

Fig.6 Scene of the spearing the turtle, Edfu temple, exterior wall of the

Pronaos, west side, $3^{\text {rd }}$ register, $26^{\text {th }}$ table

Chassinnat, Émile, Le temple d'Edfou, vol.14, Institut

Français d'Archéologie Orientale, 1934, Pl.DCXXXIV 




Fig.7 The turtle surrounded with four red crowns on the ceiling of the pronaos of Esna

Gutbub, Adolphe, 'La tortue animal cosmique bénéfique', Hommages à Serge Sauneron I, Égypte pharaonique, Cairo, 1979, 392, fig.1.

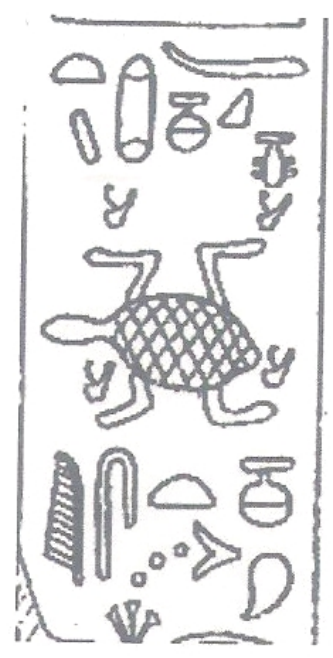

Fig.8 The turtle surrounded with four red crowns in the hymn of Sobek on the pylon of Kom Ombo

Gutbub, Adolphe, 'La tortue animal cosmique bénéfique', 393, fig.2. 


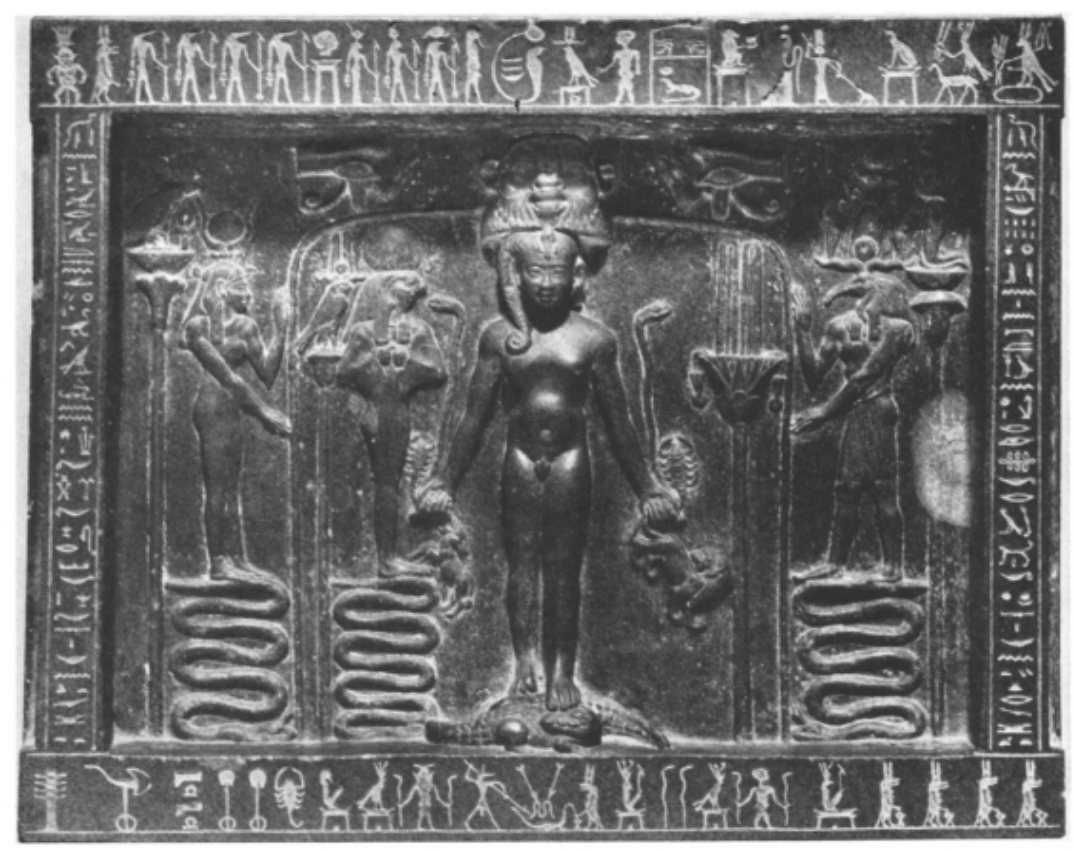

Fig.9 Horus eleminats the evil creatures, the obverse of Metternich Stela Scott, Nora E., 'The Metternich Stela', in The Metropolitan Museum of Art Bulletin 9, No.8, 1951, 206.

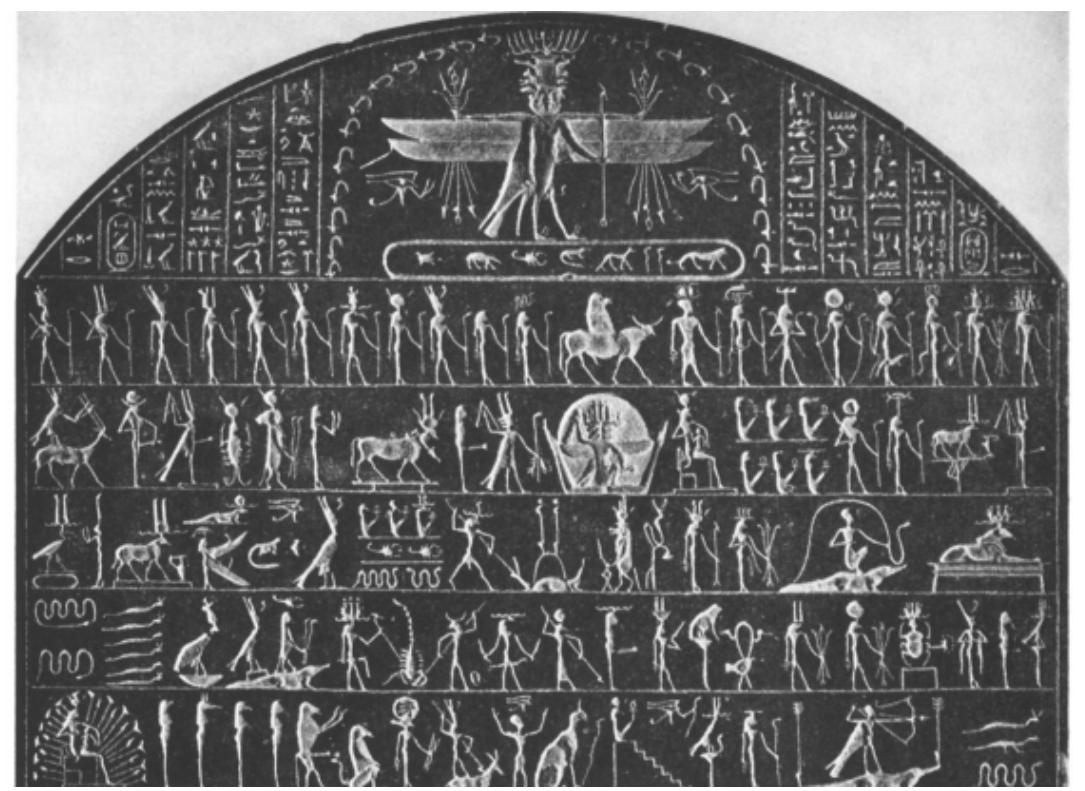

Fig.10 A mythical god standing on a circle of evil creatures, reverse of Metternich Stela

Scott, Nora E., 'The Metternich Stela', 208 